\title{
Perspectives on Justice in the Future Energy System: A Dutch Treat
}

\author{
Aad Correljé
}

\begin{abstract}
The (un)affordability, the (un)reliability and the (un)sustainability of our energy supply are increasingly associated with the phenomenon of energy justice. This concerns the way in which different groups of citizens and businesses experience the benefits and burdens of the energy transition. We explore how the concept of energy justice may support a just transition. Firstly, we address the socio-political embedding of the energy sector and policy-making. Then we explain how the concept of energy justice is defined and operationalized, in respect of policy making and implementation. Thereupon we apply the concept of energy justice to the current Dutch energy debate, addressing the reduction of natural gas production to diminish the number and strength of earthquakes in Groningen, and the longer-term policy objectives of the energy transition. It addresses the radical changes in energy use and supply and the consequent wide variety in direct and indirect consequences for citizens and businesses, depending on their specific circumstances. The notion of energy justice is discussed as a feature in local, national and EU policy making and implementation, and as a claim of social actors, communities and individuals. The suggestion that justice issues can be identified and solved at these levels, is too simple. It is important to consider the layout and nature of the socio-technical energy system and its functioning. It is concluded that the concept of justice may help researchers to identify the relevant values and value conflicts in the energy transition. This can help policymakers to make informed choices.
\end{abstract}

\section{Introduction}

It can be argued that the traditional trinity of energy policy objectives-affordable, reliable and sustainable - is facing competition from a fourth candidate target: energy justice. This looks like an interesting proposition. Of course, we want energy supply, as the driving force of our society as a whole, as well as of the social functioning

\footnotetext{
A. Correljé $(\varangle)$

Faculty of Technology, Policy and Management (TBM), Delft University of Technology, Delft, The Netherlands

e-mail: A.F.Correlje@tudelft.nl
} 
of the individuals being part of it, to fulfil the three traditional objectives. Yet, it is equally important to have an eye for the ethics of a just distribution of the benefits and burdens that are associated with the provision of energy to society.

In the public debate, the (un)affordability, the (un)reliability and the (un)sustainability of our energy supply, now and in the future, are increasingly associated with the phenomenon of justice. This often concerns the way in which different groups of citizens and businesses, to a greater or lesser extent, experience the benefits and burdens of the current system of energy supply. Yet, it is particularly in the context of the energy transition and the drastic changes foreseen that energy justice is brought in as a major policy objective. Indeed, citizens will experience such changes, for example, in their role as homeowner or tenant, as residents of a specific municipality, as a member of a local community living near a particular energy installation, as a traveller, as a consumer, as a saver or shareholder, as a taxpayer, as an employee, and in their social awareness, or-very personallyin their mental well-being. Businesses will also experience the transition, either as consumers or producers and suppliers of energy. It will change their operational processes and investment decisions and their purchasing and selling activities in markets. It will also influence their relations with governments when it comes to the awarding of permits and licenses, the impact of taxes and subsidies, and ultimately in their business results.

The direct consequences of the energy transition can be positive for citizens, in the sense that their living environment, housing, employment and their opportunities for transport improve. For some businesses new activities and opportunities will arise. Others will suffer a decline. Moreover, there are the generic advantages of curbing the greenhouse effect and of other improvements to the living environment and nature. These advantages will be felt more or less strongly in different places. On the other hand, there are the negative consequences, in terms of the financial and social costs of introducing new technologies and the scrapping of old, businesses and regions going into decline, adaptation to new patterns, routines and practices, and also 'new' damages to the quality of living and living environment (Kooger et al., 2017; SER, 2018).

As these advantages and disadvantages will be spread in an unequal way among (groups of) citizens, businesses and localities, there clearly is a distributional issue at stake. The fact that this may arouse social discontent about the distribution of benefits and burdens is seen as a functional impairment of societal support and creating resistances against the transition (SER, 2017: 12). Moreover, also an important ethical issue arises here. This particularly concerns inequality, firstly, in the degree to which citizens will experience the direct effects of the transition and, secondly, in the way in which they are socially and economically able and capable to adjust their daily life and practices, to give a positive interpretation to the necessary changes (See Kooger et al., 2017).

In this paper we want to explore what the contribution of the concept of energy justice can be to a (just) transition and what new insights this may generate. For some time now, the notion of Energy Justice is put forward as a conceptual framework. It should enable us to determine whether certain developments in the energy system 
can be judged as "just" or ethically justifiable, or not. The aim of energy justice as a scientific approach is "to provide all individuals, across all areas, with safe, affordable and sustainable energy" (McCauley et al., 2013).

The question thus arises what 'just' may mean in the context of the provision of energy. Inspired by the doctrines of environmental and climate justice, McCauley et al. (2013) suggest three basic forms, or core tenets, of justice: (1) distributive justice, questioning how the benefits and burdens of energy supply and energy use are (spatially) divided among groups of people; (2) procedural justice, questioning how decision-making processes provide access to and participation to particular social groups and in which way; and (3) justice through recognition, defined as the need to recognize the dignity and rights of all individuals and the need for them to be included and therefore avoid the conditions of deprivation (such as that of fuel poverty). This addresses the way in which social, cultural, locational and other aspects structurally influence the exposure of groups to benefits and burdens and their capacity to deal with them. Recognition is then a precondition for trust and involvement and providing compensation.

Sovacool and Dworkin (2015) present energy justice as a conceptual approach. First, to relate various questions of justice to the provision and use of energy. Secondly, as an analytical approach for researchers to identify and operationalize the different values that play a role in the energy system. And thirdly, as a deliberative instrument for policy makers enabling them to arrive at more informed choices and policies. Jenkins (2018: 120) adds that energy justice offers a clearer focus on energy systems than the broader notions of environmental and climate justice because it develops an explicit energy focused methodology.

In the first section we will address the socio-political embedding of the energy sector and policy-making. Of importance is its evolution from a public service driven utility system in the past, to a more market-oriented-yet publicly coordinatedservice focusing on efficiency, and more recently towards an energy system that is primarily driven by sustainability goals, in terms of a reduction of $\mathrm{CO}_{2}$ emissions. We argue that an energy transition in a liberalized energy sector requires explicit attention for issues of energy justice. Indeed, there will be a great diversity in the way different (groups of) citizens and businesses will experience the consequences of the transition. This will be highly dependent on their specific social and economic circumstances, creating large contrasts in their possibilities to anticipate and to respond to the changing conditions under which energy will be supplied.

This motivates a more thorough examination of the concept of energy justice. Section "Public Values and Energy Supply" explains how the concept of energy justice is defined and operationalized in the academic literature, and provides possible connections with the practice of policy making and implementation.

Subsequently, in Section "Energy Justice", we will examine how the concept of energy justice may be applied in unravelling the current Dutch energy debate. In this debate, two policy objectives are paramount; firstly, on short notice, there is the need to reduce the supply of natural gas from the huge Groningen field, in order to diminish the number and strength of the earthquakes caused by the ongoing depletion of this field. Secondly, there is the longer term policy objective of the energy transition, 
requiring policy measures to be taken in the very near term, as well. In this context, we will discuss the notion of energy justice as an argument in national and local policy making, as a feature of the policy implementation at various levels (European Union, Netherlands, municipalities), and as a claim of social actors, communities and individuals. Finally, we will briefly address the question of how the concept of justice can contribute to a socially responsible policy for the energy transition (Section "Values in the Energy Transition").

\section{Public Values and Energy Supply}

The social importance of energy is nothing new. Energy supply systems and energy use always have had a strong influence on the social and economic functioning of societies, the people and their activities, and vice versa. This applies both to the availability of energy resources, as well as to the governance of the system of energy provision, within the prevailing socio-political context (see Goudsblom, 2001). The functioning of energy supply systems and their impact on society has attracted attention already for centuries; the impact of the peat dredging on water safety in eighteenth century Holland being a case in point (Rooijendijk, 2009). The notion of energy supply as a utility service arose in the beginning of the twentieth century. In Europe, the public values attached to the expansion of energy supply led to the establishment of public gas and power utilities, controlled by local and national authorities (Milward, 2005). Since the 1980s, we have seen a shift from public utility to market coordination, in which government only intervenes when and where necessary. Energy was transformed from a utility into a private commodity (De Jong et al., 2005).

\section{Energy Supply as a Utility Sector}

Over time, the pursuit of an affordable and reliable, and later also a sustainable, energy supply, has been given shape in different ways depending on the era. This has regularly led to debates and political discussions about the organization and the instrumentation of the supply of energy. Examples of these debates are the conversion of private gas and electricity companies into public, municipal, utilities in the first decades of the twentieth century; the large-scale introduction of natural gas in the 1960s; and the liberal restructuring of the energy sector during the 1990s (Hesselmans \& Verbong, 2000; Hesselmans et al., 2000a, b, Correljé \& Verbong, 2004). Obviously, such debates concerned distributive issues relating to tariffs and taxation and access to services and facilities. Later on, they also involved safety and environmental issues; like the broad public debate around nuclear energy in the early 1980s, acid rain, unleaded gasoline and the debate about responsible gas exploitation in the Waddensea nature reserve and the issue of compensation, at the beginning of this 
century. A variety of energy-related values were defined, articulated and placed on the political agenda, as an issue of public interest in evolving societal and political discussions (De Jong et al., 2005; van der Linde 2008; Groenewegen and Correljé 2009).

\section{Social Acceptance and Energy Infrastructure}

Over the past ten years, however, we have seen a development in which, in addition to the traditional discussions on public interests in energy supply, controversies with groups of citizens and companies are sharpening. These citizens oppose the way in which they experience the benefits and burdens of particular aspects of the current energy supply system and of the changes foreseen whether or not as part of the energy transition. This generally often involves situations where the perceived burdens affect individuals and (local) interest groups, whereas the benefits fall to society in a broader sense. Improved connections within the gas and electricity networks and with neighbouring countries facilitate the functioning of the market, with likely benefits in terms of lower prices, consumer choice, security of supply and business activity. Substantial measures are also being taken to create a low-carbon energy production on a larger scale, supplying green electricity and gas.

The consequences of these developments are the emergence of controversies around high-voltage lines, underground gas and $\mathrm{CO}_{2}$ storage projects, on- and offshore wind farms, solar parks, shale and natural gas production, geothermal projects, and so on. This phenomenon also occurs around other infrastructures, such as those for transport, telecom, water management and water safety, and in spatial planning when it comes to the development of new residential and work locations.

In this context, the issue of social acceptance has come to life. It has become clear that although the construction of such infrastructural works serves a public good for all, this does not preclude resistance of concerned (groups of) local residents and of citizens in general, who reject the damage and disturbances to their living environment, nature and landscape, or question the necessity of a specific provision. Moreover, it is recognized that discussing 'social acceptance' not necessarily means that the ethically important aspects of the energy discussion are on the debating table (Taebi, 2017). In recent years, in the Netherlands, we have seen a number of delayed or failed projects, among which an underground $\mathrm{CO}_{2}$ storage in Barendrecht and the exploration for shale gas. We also observe that, in response to these failures, operators of infrastructures to be built and governments involved are formulating their motivation in terms of usefulness and necessity. They also engage in information processes about the progress and impact of the projects, in the guidance and participation of local residents and in compensation measures. Attention to the 'management of the social environment' has become part of the public-private interaction around such infrastructures, in law and planning, in tendering conditions and in awarding permits (van de Grift et al., 2020). 
This, however, does not mean that the construction of new infrastructures is now without problems. Referring to the concept of justice, it can be said that citizens frequently consider that it is unfair that they are affected in their living environment by the construction of infrastructures, although they generally support the pursuit of a sustainable and reliable energy supply at the same time. The formulation of usefulness and necessity in abstract terms, and the way in which external effects and risks are defined and allocated to specific groups of citizens, remain a source of controversy. Citizen participation and information do not always have the desired effect when it comes to reaching agreement and are often regarded as an arrangement to 'buy' acquiescence from the 'public' (Correljé et al., 2015; Cuppen et al., 2015, 2016; Taebi, 2017).

We also see the emergence of gaps between priorities at the national and the local government. Where energy objectives are formulated at national level that require the local installation of plants, factories and transport infrastructure, discussions arise between the national and local authorities about where and how these should be built. Nationally formulated values, such as the reliability and affordability of energy supply and sustainability in terms of a reduction in $\mathrm{CO}_{2}$ emissions, clash with local values in regarding the environment, nature, safety, the related local economic interests, and ultimately with the voice of local politics (Correljé, 2017).

\section{The Energy Transition Enters the Front Door}

In respect of the energy transition, it is clear that the necessary changes to the energy system will be even more intrusive and come closer to the citizen. Of course, there are (groups of) citizens who enthusiastically embrace this perspective and take every opportunity to provide themselves with sustainable energy. However, many more citizens will face the changes in their environment, their pattern of living, their work and travel habits and their pattern of consuming with less enthusiasm. And, as stated by the Minister of Economic Affairs and Climate, Wiebes: "If the household wallet starts to suffer too much as a result of the transition, initial support will disappear quickly." (Translated from MEZK 2018).

Moreover, with the recent announcement that Dutch households will have to say goodbye to natural gas as a primary source of energy in their domestic heating and hot water supply, the energy transition enters the front door. With regard to their household wallet, their social awareness, their involvement and their comfort at home and well-being, citizens will appreciate the effects of the energy transition in rather diverse ways. And that will depend on where they live and in what kind of houses, what work they (can) do and where, what their patterns of consumption and leisure activities are, and what their (financial) capacities and possibilities for adjustment are. 


\section{Energy Justice}

As stated earlier, the concept of energy justice is rooted in environmental and climate justice, where three generic forms are recognized: (1) distributive justice, where the question is how the benefits and burdens of energy supply and energy use are divided among groups of people; (2) procedural justice, which poses the question of how the decision-making process for energy supply works, who has access to and participation in it and in which way; and (3) justice through recognition, whereby it is stated that there may be a distinction between the way in which social, cultural, locational and other aspects can structurally influence the exposure of groups to benefits and burdens and their capacity to deal with them (Jenkins et al., 2016; McCauley et al., 2013). We therewith have an abstract framework that helps us to have an eye for who gets what (not), in what process that has been decided and whose positions have been taken into account. Over time this triple framework has been given substance and elaboration; on the one hand to increase the analytical power and to make it more explicit, and on the other to make it usable for practical policy issues.

Sovacool et al. (2016) suggest an alternative, but at the same time overlapping and complementary, framework. The three aforementioned perspectives are further elaborated on in the form of eight principles that should operationalize the concept of energy justice. These principles include, in terms of distributive justice: (1) availability, (2) affordability, (3) fairness between members of a generation (equity), (4) fairness between members of different generations and (5) sustainability. Regarding procedural justice, the following principles are important: (6) due process, (7) transparency and accountability, and (8) responsibility. The phenomenon of recognition seems to be connected with (9) due process and (10) responsibility.

\section{Justice Assessment in the Energy System}

Heffron and McCauley (2014) proposed to use the framework in the context of the entire energy system, where each segment of the energy chain is assessed from a justice perspective. The energy sub-systems generally consist of a number of vertically connected segments: production, transport, processing and consumption. Heffron and McCauley (2017: 660) underline the role of restorative justice, whereby energy justice can be created in the energy chain, in relation to the nature of the damages caused in certain segments. The idea is that attention and intervention are not only focused on punishing the perpetrator, but also on repairing damage to victims, society or nature, or proactively preventing damage. Balancing the costs of that prevention and/or recovery against the benefits could then lead to a rational termination or adjustment of the harmful activity. In fact, this way of thinking argues in terms of the economic concept of negative external effects, where the complete assignment of property rights to the parties involved gives rise to negotiations about monetary 
compensation, measures of repair, or relocation or termination of the activity (Coase, 1960).

However, the energy system and its several supply—or value-chains can be defined in many ways. The end product that is delivered to the consumer can be leading, such as the supply of oil products, gas, electricity and heat. The primary energy source can be leading, such as crude oil, coal, natural gas, nuclear energy, hydropower, wind, sun, biomass and geothermal energy, and so on. The energy service to be supplied can also be leading, such as heat, power, light, and-evendata transport. The question of how specific 'external' effects somewhere in such a chain, giving rise to occurrences of justice and injustice, can logically be assigned to the consecutive segments and the actors may cause a hop-and-skip argumentation.

Indeed, should all Dutch domestic households be forced to overhaul their energy appliances and stop using natural gas, just for the sake of reducing the earthquakes caused by the production of gas in Groningen? Should we consider to tax natural gas on the basis of $\mathrm{CO}_{2}$ and methane emissions arising from the transport of gas imported from Siberia, or environmental damages of shale gas production in the US? Is it fair to tax domestic gas consumers while reducing electricity taxes, when most of this electricity - particularly at peak demand - is produced with gas fired power plants? Indeed, there are always many technical, economic and institutional dependencies between the segments in a system, however defined. How do we deal with the possibilities for substitution of primary energy sources, technologies and end products in the provision of essential energy services: heat, power, light and communication and data transport? Should we provide untaxed power to electric vehicles?

And even with regard to services, there is a degree of substitution potential, for example when it comes to (tele) communication versus transport or the use of energy to construct low-energy houses versus heating those houses with gas. Either of those alternatives will use energy of whatever origin, with particular consequences and effects. As a consequence, it makes little sense to simply link particular situations of injustice of any kind in up- or downstream segments of a supply chain, to actions and interventions in either the use and consumption sphere, or the production segment. The problems are almost always much more complex.

\section{Energy Justice in a Multi-level Framework}

An alternative approach in applying the notion of energy justice is suggested by Jenkins et al. (2018), with the multi-level perspective approach (MLP) of the socio-technical system serving as a framework (Cherp et al., 2018; Geels, 2002). Bouzarovski and Simcock (2017) and Sovacool et al. (2019) take a similar approach to which they add the notion of space; identifying injustices at the scale of the community, the nation or region, or the global scale. In the MLP context, occurrences of energy (in)justice are linked to three different levels: the niche, the socio-technical regime and the landscape. It is the interaction between developments at the level of 
the niches and the socio-technical system (and within that), and in the context of the landscape, that transitions are given shape.

At the level of the niche( $s$ ) we find concrete, more or less innovative, applications of technologies or systems under development, such as electric cars, individual or neighborhood batteries, or biogas installations. Developments in niches are dynamic and their embedding in technical and institutional frameworks has often not crystallized yet. A justice perspective applied at this level should make it possible to identify potential sources and forms of injustice at an early stage. Technological adjustments can be proposed and assessed with these insights. Aspects of an appropriate institutional embedding, in terms of rules of conduct, norms and standards, can be explored, with which social acceptance can be strengthened. We see here a possible application of concepts such as socially responsible innovation (MVI) (Taebi et al., 2014). Nevertheless, we stress that at the niche level it is impossible to make a full evaluation of the institutional embedding of such new technologies. This only comes to light at the level of the socio-technical regime and larger scale implementation, when issues of economic, market, technical, social and system coordination become important and have to be addressed.

At the level of the socio-technical regime, the established technological systems, their institutional embedding, the resulting routines and practices and their social effects are examined. The regime creates stability and gives direction to further technological developments and to the behavior of public and private actors. Changes in the regime take place under the influence of the dynamics within the regime and as a result of developments in the niches, also influenced by landscape shifts. At the regime level, as argued by Jenkins et al. (2018), energy justice can play a role in mapping and evaluating the social, economic and ecological effects of the functioning of (parts of) technical systems, such as the electricity or gas supply infrastructures, district heating networks, wind parks, electric vehicle loading systems, etc. The establishment of normative criteria and assessment frameworks can help policy makers and companies to assess the functioning of those systems, as well as the possible changes therein. Here it can be checked to what extent such systems meet the social requirements in terms of distributive and procedural justice, and of justice through recognition regarding the impact on those involved.

The third level of the MLP concerns the macro landscape (Jenkins et al., 2018: 70). Here we find the embedding of actors and institutions in a relatively stable social and global context of political, social and cultural values, including knowledge and scientific insights. The landscape level in the MLP literature is usually considered static and inhibitory or facilitating. However, here we also see elements that sometimes change relatively quickly and thus influence the notion of energy justice and its application. Examples are the way in which the behavior of multinational companies and the role of the state in the economy is evaluated. It also may concern international relations, developments in the oil and gas market and, for example, the consequences of the nuclear disaster in Fukushima. Other shift parameters include the development of new knowledge and insights into the effects of energy use on climate change and the consequences thereof. Such phenomena influence the identification and societal and political assessment of aspects of energy justice. These, in turn, influence how 
the argumentation and evaluation is conducted at the lower two levels, giving rise to shifts within the regimes and to innovation in (new) niches.

It can be argued that the positioning of energy justice in relation to the goals of affordability, reliability and sustainability partly takes shape at the level of the landscape. Examples are the expectation of higher oil prices in the future due to depletion and the power of OPEC, the risks of EU gas dependence on Russia, the hazards of nuclear energy, the expected consequences of global warming and the deterioration of the Arctic by oil and gas extraction, and so on.

\section{Identification of Claims of Energy Justice}

With regard to each of the three levels, the question can of course be asked how claims of energy (in) justice can be identified, and whether or not they will have an effect in concrete policies or strategies (Pesch et al., 2017a). Building on the above, Pesch et al. suggest an approach in which the role of controversy and conflict around energy (projects) is central. Controversy is seen as an indicator to identify injustices and helps to understand how such claims, either or not, are articulated and accepted as a relevant public value. To this end, a distinction is made between, on the one hand, the legally established formal evaluation process, be it in the form of macro-economic or environmental models, or as (Societal) Cost Benefit Analysis, Environmental Impact Assessment and licensing and planning procedures. On the other hand, however, there is an informal social process, which takes place in the public discourse and can take many forms. The emergence and growth of public protest about particular forms of energy (projects) can be seen as an (alleged) lack of attention to certain social values in the formal process (Pesch et al., 2017b).

In the public and political debate, such values may be articulated and then be included in the formal policy process, or not. In the occurrence of such controversies there are three characteristic differences between the two trajectories. Firstly, in the way in which values are expressed, the formal process usually involves a legally and technically defined rationality, whereas stories and shared experience and feelings are central to the informal process. This results in diverging claims for justice. Secondly, procedural justice is dominant in the formal process, determining the way in which recognition and distributive justice are taken into consideration. On the other hand, the justice of recognition is often central to the informal process, distinguishing how different societal groups are affected to their own feeling. Thirdly, the moral conviction in both processes is based on different democratic principles. On the one hand there is the formality of institutionally guaranteed and legally established rules from which parties derive rights, and on the other hand it is often about moral self-determination of citizens who belong to a specific community (Pesch et al., 2017a).

By not considering both processes as separate, but by seeing them in relation to each other, (possible) injustices can be identified, understood and discussed. That may, or may not, lead to adjustments. This may enable us to use (in)justice as a useful 
concept with which controversies around the energy supply can be understood and assessed. Energy justice thus may become, as Sovacool and Dworkin (2014: 20) state: "an appropriate orientation for considering, balancing and prioritizing various justice claims that arise in energy patterns and decisions". This, however, is not a straightforward exercise, as will be shown in the following section.

\section{Values in the Energy Transition}

\section{The Landscape Level}

In the Netherlands, citizens are increasingly confronted with the effects of the energy transition, as agreed in the Paris agreements and the European objectives in the area of $\mathrm{CO}_{2}$ emission reduction, and elaborated in Dutch policy measures. Here the global objective is translated into a European timetable of national emissions, the Green Deal. It is then implemented by the EU member states as more or less concrete, sectorally oriented, transition targets at the national level. Knowledge development and changing insights into $\mathrm{CO}_{2}$ emissions and climate change at the level of the landscape give rise to justice claims with regard to the existing energy regime(s). It is clear that a complex set of values, related to the effects of global warming, is linked to the nature and structure of the Netherlands' energy system.

\section{The Socio Technical System Level}

Increasingly, policy measures are being taken to make energy supply more sustainable in terms of $\mathrm{CO}_{2}$ emissions, such as in the Dutch Energy Agreements and the Regional Energy Strategies. Examples at the system level are the construction of wind farms and solar fields, the closure of the older coal-fired power stations and the reduction of the role of natural gas in the energy mix. In recent years there has also been an increase at the local, municipal, level of initiatives for sustainability in the built environment, the transport sector and in the energy consumption of the public sector (Weijnen et al., 2015). But when implementing this policy, in particular in the form of wind and solar parks, we also see that the loss of all kinds of local values is questioned as being unjust.

In parallel, a second important shift is taking place at the system level. Since the mid-1960s, based on the discovery of a huge gas field in Groningen, natural gas has evolved as the main source of energy fuelling Dutch households and economic production (Correljé et al., 2003). As from the early 1990s, the province of Groningen was hit by earthquakes as a result of the production of gas from the field that extends under a large part of the province. Over time, with the pressure in the depleting field decreasing, those earthquakes have augmented in number and force. This gave 
rise to increasingly powerful protests from the inhabitants of Groningen, who found themselves supported by their local politicians and later also by national politics. The deterioration of safety and the destruction of property led to justice claims that related not only to the distribution of benefits and burdens of gas production, but alsopossibly even more - to the long-awaited recognition (and even the initial denial) of the relationship between gas production and earthquakes, and the consequences for the inhabitants. Lack of procedural justice is also generating fierce criticism. This involves both the decision-making process by the Minister of Economic Affairs concerning the scale of the annual production of gas, as well as execution of the compensatory procedure for damages, as legally provided. Recently, the notion of flawed procedural justice has also been applied in respect of the procedures and implementation of a programme by which existing houses and buildings will be reinforced, to withstand possible future earthquakes (van den Beukel \& van Geuns, 2019; Van der Voort \& Vanclay, 2015).

These justice claims and their political articulation led to action. Gas extraction was thus reduced in a few steps. The formal motivation for this lies in a number of "recommendations" from the State Supervision of Mines (SodM) and various investigations into the trade-off between gas production, earthquake risk and the security of gas supply. Nevertheless, the Council of State ruled in November 2017 that the minister had to take a new and better substantiated decision. The risk to the people in the earthquake zone was not sufficiently taken into consideration in the justification. Nor was it sufficiently motivated why security of supply was taken as the lower limit for the amount of gas to be extracted, despite the uncertainty about the consequences. Moreover, it was not made clear what measures are actually feasible to limit the need for a specific volume gas (Raad van State, 2017).

After the unexpectedly severe earthquake at Zeerijp in January 2018, the SodM recommended a production of 12 billion $\mathrm{m}^{3}$ per year. In March, however, the government announced that the gas production in the Groningen field would have to be terminated as quickly as possible, to avoid a further increase of the earthquake risk, and to restore the perception of safety for the inhabitants. This implies that the field will not be fully depleted. By the end of 2022, gas extraction must have fallen to below 12 billion $\mathrm{m}^{3}$ per year. Depending on the effect of the measures to reduce gas consumption, a decrease is expected from October 2022 to 7.5 billion $\mathrm{m}^{3}$ and possibly less. Moreover, by 2022 all 170 large-scale industrial consumers of Groningen gas must have switched to high-calorific gas or alternative energy sources. Also, with foreign buyers of Groningen gas, in northern Germany, France and Belgium, arrangements are struck to accelerate the reduction of their gas consumption. After 2022, gas extraction will be further reduced to zero (MEZK, 2018; Beukel \& Geuns, 2020; Beukel \& Beckman, 2019).

At the level of the socio-technical system, at first sight, we see a policy that is inspired by securing the value of solidarity and safety for the people of Groningen. Indeed, the right to extract gas from the Groningen field by the NAM, a joint venture of Shell and Exxon-Mobil, as agreed with the Dutch State and laid down in a policy paper in 1962, is severely restricted. In the second instance, however, we see a different, much more complex, pattern of values at stake. Firstly, alongside a reduction in the 
Groningen production, it is quite possible to import high-calorific gas from Norway, Russia or elsewhere in the form of LNG. However, this requires an investment by Gasunie in additional transport infrastructure and the construction of a nitrogen plant to "dilute" that gas to the quality of Groningen gas. The costs of this are borne by all gas consumers in the Netherlands, given the current mechanism of cost socialization. This implies, at the regime level, a weakening of the value of affordability via the regulated transport tariffs, in particular for those consumers who must continue to use gas because they have no alternative. Secondly, it means that more gas has to be imported into the Netherlands and therefore into Europe, which can be seen as an impairment of the value of energy independence or reliability, especially with regard to Russia. In the current international political context in Europe, this is a difficult issue at the landscape level. Thirdly, it is often said that the pace at which the Netherlands could switch off from gas — as a fossil fuel-would be delayed, when foreign gas would be imported to replace Groningen gas. This would put the value of sustainability at stake in the longer term, depending on how that Groningen gas is going to be replaced by alternatives. And, on the shorter term, sustainability will be jeopardized by larger $\mathrm{CO}_{2}$ and methane emissions associated with gas imported from Russia, or as liquefied shale gas from the US.

\section{The Niche Level}

The initial plans to reduce the gas production in Groningen, in combination with the pursuit of $\mathrm{CO}_{2}$ emission reduction, had already convinced a number of Dutch municipalities that they should voluntarily say goodbye to natural gas. What certainly contributed to this was the growing criticism of natural gas as a source of energy and of the governance of the gas industry in the Netherlands, also inspired by the protests against shale gas development (Correljé, 2017). Nevertheless, the decision to phase out gas production in Groningen before the field would be depleted requires a significant acceleration of this conversion. Newly constructed and renovated buildings will have to be (re)constructed gasless. Over the slightly longer term, a gradual disconnection of gas will have to take place in the existing built environment. To that end, municipalities are committed to developing regional transition plans.

Therewith, as stated above, the energy transition crosses the threshold of the frontdoor. From a technical point of view, citizens are now confronted with an uncertain action perspective regarding alternative heating solutions. Technologically speaking, heat pumps are still in their infancy compared to the current high-efficiency gas boilers. Heat networks still have a long way to go in terms of their institutional embedding, possible business models and their technical development. In addition, it is clear that a large variation in the living environment and types of housing will lead to major differences in suitability and switching costs with regard to new forms of heating and thermal insulation. What also seems important here is that from a relatively homogeneous situation, in which energy similar to water and the sewage services is provided at standardized conditions, we may see a rapid shift to a much 
larger diversity in supply conditions, depending on the specific circumstances of the individual users.

This is also the case when it comes to IT facilities. What makes a difference here is that the telecom sector (fixed telephony, cable companies and mobile telephony) has now gone through a relatively long period of competitive technology and market development. So a variety of more or less similar solutions is available. Yet, there are still significant (local) differences in the quality and costs of provision.

Generally, the role of smart grids, ICT and digital platforms is seen as a great promise to facilitate a new, smart, sustainable and efficient provision of energy services. That could well be, given the opportunities of ICT-based platforms in coordinating supply and demand, the allocation of production, transport and storage capacities, and the allocation of costs and benefits to the users of those smart energy systems. Nevertheless, there is an important point of attention as such systems can process the collected information in all sorts of ways. The information and coordinative mechanisms provided can be used not only very smartly, but also shrewdly and strategically, to profitably discriminate among users. Depending on the governance of such smart grids, discrimination among the various groups of users can take place, depending on their capabilities to act and react (Van Dijck et al., 2016). It is obvious that justice issues of recognition and distribution are at stake here that require attention.

It is obvious that the course of the transition at the local level, in terms of costs, quality and comfort for citizens and businesses, and regarding the process itself, will be highly dependent on the ownership relations, the capacity and the cooperation of municipalities, network managers, project developers, housing associations, the construction sector and installation companies, and any new parties. It is already clear that this will lead to highly varying circumstances in different municipalities, where the size and capacity and local politics will be determining factors in their effectiveness in coordinating a 'just' transition.

In addition to the direct consequences of the transition for the energy supply of citizens and companies, it is to be expected that radical second-order effects will occur. Residents of local communities, neighborhoods and municipalities will be confronted with the construction of new energy systems, new technologies and new infrastructures, with new effects on their living environment. Citizens will have to adjust their travel behavior when it comes to commuting, necessary journeys for education, medical and other services, and leisure activities. As employees in particular economic sectors, they may be confronted with radical changes in business processes, or possibly even with the termination thereof. This will be accompanied by new activities, that place new demands on training and knowledge development. On a local scale this can have important positive or negative influences on (the structure of) employment and the supply of labor (see Kooger et al., 2017; SER, 2018).

Citizens will tend to judge the consequences of these changes in terms of justice. Above it has been stated that large differences may arise between groups of people, depending on where they live and in what type of houses, their work, their patterns of consumption and leisure activities, and their (financial) capacities and possibilities for adjustment. This involves distributive justice in respect of the question of 
how the benefits and burdens of new forms of energy supply and use are distributed among those groups of people. Justice through recognition seems necessary to gain access to those different groups of citizens and to get a picture of what consequences they will experience from the changes. From there, it can be considered which specific approach is most suitable, with regard to the technologies to be used, the means for financing, providing support and information, and so on. Procedural justice also requires understandable, foreseeable, decision-making and implementation processes that facilitate insight, access and participation where necessary in a credible and consistent manner.

\section{Conclusion}

How can the concept of justice contribute to a socially responsible policy for the energy transition? Sovacool and Dworkin (2015) argue that it allows us to link different issues of justice around energy. As an analytical approach, it could help researchers to identify the various relevant values at stake in the system of energy provision. This can help policymakers to make informed choices. To do so, it appears to be of great importance to consider the nature of the socio-technical system of energy provision, its functioning, and its specific local layout.

Above we have demonstrated that the evolution of the energy system is increasingly driven by sustainability goals at the level of the landscape in the form of $\mathrm{CO}_{2}$ emission reduction, and specifically for the Netherlands' energy system, the decision to reduce the gas production in Groningen. This will lead to radical changes in the energy supply, which will have both direct and indirect consequences for citizens and businesses. The advancing energy transition is likely to show a wide variety in the consequences experienced by citizens and businesses, depending on their specific circumstances. We expect to see great contrasts in their ability to respond to these changing conditions in energy use and provision.

The concept of energy justice provides a starting point in terms of the distinction between distributive and procedural justice and justice through recognition. In particular, the recognition of the major differences in benefits and burdens and in the perspective for action between groups of citizens appears as an essential element for a socially responsible transition process and for the selection of suitable policy instruments. The suggestion, however, that justice issues can be identified and solved at the various niche, regime and global levels, is too simple. Solving such issues will always cause new value conflicts and situations of injustice at and between the different levels.

There is no straightforward way to avoid conflicts. However, understanding these conflicts can be helpful in identifying injustices and concretising values that appear to be compromised. At the niche level, a justice perspective applied to new options for energy supply in a particular environment makes it possible to identify possible sources and forms of injustice at an early stage. Technological adjustments and social aspects can be proposed and discussed with these insights. 
At the system level, aspects of an appropriate formal institutional embedding can be explored, in terms of the rules of the game, financial and economic coordination, norms and standards, and planning and phasing. This is a learning trajectory in which the experiences of actors, the effects of upscaling and the associated institutional and technological development may gradually lead to new insights and possibilities.

A particular challenge lies in dealing with the characteristic differences between the way in which values are expressed and used as a justice claim in formal and informal valuation processes. It is clear that justice of recognition must be a crucial aspect of the interaction. In addition, some sensitivity in understanding and interpretation will be needed to translate the stories, experiences and feelings of citizens, but also those of public and private organizations, into the values that must be taken into account in decision-making and in the institutional embedding of the energy transition (see also Jenkins et al., 2020). There is no doubt about the need for procedural justice. That has been clearly demonstrated in the Groningen case, where the faltering approach to recognition, recovery and compensation has contributed to institutionalized mutual mistrust between residents, local and national government and the gas industry. A perceived lack of procedural justice seems a guarantee that the moral self-determination of citizens in their community will turn against the energy transition and the authorities and businesses involved. In a context in which all institutions, knowledge, considerations and technologies will be questioned anyway, it then becomes difficult to reach any kind of workable consensus.

\section{References}

Bouzarovski, S., \& Simcock, N. (2017). Spatializing energy justice. Energy Policy, 107, 640-648 Cherp, A., Vinichenko, V., Jewell, J., Brutschin, E., \& Sovacool, B. K. (2018). Integrating technoeconomic, socio-technical and political perspectives on national energy transitions: A metatheoretical framework. Energy Research \& Social Science, 37, 175-190

Coase, R. (1960). The problem of social cost. Journal of Law and Economics, 3, 1-44

Correljé, A. (2017) The Netherlands: Resource management and civil society in the natural gas sector. In Indra Overland (Ed) Public brainpower: Civil society and natural resource management. Pallgrave/Macmillan, London.

Correljé, A., Van der Linde, C., \& Westerwoudt, T. (2003). Natural gas in the Netherlands. From cooperation to competition?

Correljé, A., \& Verbong, G. (2004). The Transition from coal to gas: Radical change of the Dutch gas system. In B. Elzen, F. Geels, \& K. Green (Eds.), Break on through to the other side: Technological transitions to sustainability through system innovation (pp. 114-134). Cheltenham UK, Edward Elgar.

Correljé, A. F., Cuppen, E., Dignum, M., Pesch, U., \& Taebi, B. (2015). Responsible innovation in energy projects: Values in the design of technologies, institutions and stakeholder interactions. Responsible Innovation, 2, 183-200

Cuppen, E., Brunsting, S., Pesch, U., \& Feenstra, Y. (2015). How stakeholder interactions can reduce space for moral considerations in decision making: A contested CCS project in the Netherlands. Environment and Planning a, 47, 1963-1978

Cuppen, E., Pesch, U., Taanman, M., Remmerswaal, S. (2016) Normative diversity, conflict and transitions: shale gas in the Netherlands. Technological Forecasting and Social Change, 29. 
de Jong, J. J., Weeda, O., Westerwoudt, T., \& Correljé, A. F. (2005). Dertig jaar Nederlands energiebeleid: Van bonzen, polders en markten naar Brussel zonder koolstof. Clingendael International Energy Programme.

Geels, F. W. (2002). Technological transitions as evolutionary reconfiguration processes: A multilevel perspective and a case-study. Research Policy, 31, 1257-1274

Goudsblom, J. (2001). Vuur en beschaving. Ooievaar.

Groenewegen, J., \& Correljé, A. (2009). Public values in utility sectors; economic perspectives. International Journal of Public Policy, 4(5), 395-413

Heffron, R. J., \& McCauley, D. (2014). Achieving sustainable supply chains through energy justice. Applied Energy, 123, 435-437

Heffron, R. J., \& McCauley, D. (2017). The concept of energy justice across the disciplines. Energy Policy, 105, 658-667

Hesselmans, A. N., \& Verbong, G. P. J. (2000). Schaalvergroting en kleinschaligheid: de elektriciteitsvoorziening tot 1914', blz. 124-139 in J. Schot, H. Lintsen \& A. Rip Techniek in Nederland in de twintigste eeuw. Deel 2. Delfstoffen, energie, chemie, Eindhoven: Walburg Pers.

Hesselmans, A. N., Verbong, G. P. J. \& Buiter, H. (2000a). Binnen provinciale grenzen: de elektriciteitsvoorziening tot 1940, blz. 140-159 in J. Schot, H. Lintsen \& A. Rip Techniek in Nederland in de twintigste eeuw. Deel 2. Delfstoffen, energie, chemie, Eindhoven: Walburg Pers.

Hesselmans, A. N., Verbong, G. P. J. \& van den Berg, P. (2000b). Elektriciteitsvoorziening, overheid en industrie 1949-1970', blz. 220-237 in J. Schot, H. Lintsen \& A. Rip Techniek in Nederland in de twintigste eeuw. Deel 2. Delfstoffen, energie, chemie, Eindhoven: Walburg Pers.

Jenkins, K. (2018). 'Setting energy justice apart from the crowd: Lessons from environmental and climate justice'. Energy Research \& Social Science, 39, 117-121

Jenkins, K., McCauley, D., Heffron, R., Stephan, H., \& Rehner, R. (2016). Energy justice: A conceptual review. Energy Research \& Social Science, 11, 174-182

Jenkins, K., Sovacool, B. K., \& McCauley, D. (2018). Humanizing sociotechnical transitions through energy justice: An ethical framework for global transformative change. Energy Policy, $117,66-74$

Jenkins, K. E., Stephens, J. C., Reames, T. G., \& Hernández, D. (2020). Towards impactful energy justice research: Transforming the power of academic engagement. Energy Research \& Social Science, 67, 101510

Kooger, R., Straver, K., \& Rietkerk, M. D. A. (2017). Essay bundel 'De ethiek van de energietransitie': Inleidende essays over de winnaars en verliezers van de energietransitie. Energieonderzoek Centrum Nederland.

McCauley, D., Heffron, R., Stephan, H., \& Jenkins, K. (2013). Advancing energy justice: The triumvirate of tenets. International Energy Law Review, 32(3), 107-110

Millward, R. (2005). Private and public enterprise in europe energy, telecommunications and transport, 1830-1990 Series: Cambridge Studies in Economic History-Second Series, Cambridge.

MEZK (2018) Kst. 32813 Nr. 163 Brief van de Minister van Economische Zaken en Klimaat aan de Voorzitter van de Tweede Kamer der Staten-Generaal, Den Haag, 23 februari 2018.

Pesch, U., Correljé, A., Eefje, C., \& Taebi, B. (2017a) Energy justice and controversies: Formal and informal assessment in energy projects. Energy Policy, 109, 825-834.

Pesch, U., Correljé, A., Cuppen, E., Taebi, B., \& van de Grift, E. (2017b). Formal and informal assessment of energy technologies. In J. van den Hoven, E. J. Koops, T. Swierstra, H. Romijn, \& L. Asveld (Eds.), Responsible Innovation (Vol. 3). Springer.

Raad van State (2017) Uitspraak 201608211/1/A1. Raad van State, s'Gravenhage. https://www.raa dvanstate.nl/@109356/201608211-1-a1/. Accessed on January 07, 2020.

Rooijendijk, C. (2009). Waterwolven: Een geschiedenis van stormvloeden, dijkenbouwers en droogmakers. Atlas.

SER. (2017). Governance van het energie- en klimaatbeleid, SER Advies nr. 5, april 2017, Den Haag: Sociaal-Economische Raad.

SER. (2018). Ontwerpadvies Energietransitie en werkgelegenheid, Bestemd voor de raadsvergadering d.d. 19 April 2018, Den Haag: Sociaal-Economische Raad. 
Sovacool, B. K., \& Dworkin, M. H. (2014). Global energy Justice: Problems, principles, and practices. Cambridge University Press.

Sovacool, B. K., \& Dworkin, M. H. (2015). Energy justice: Conceptual insights and practical applications. Applied Energy, 142, 435-444

Sovacool, B., Heffron, R. J., McCauley, D., \& Goldthau, A. (2016). Energy decisions reframed as justice and ethical concerns. Nat Energy 1https://doi.org/10.1038/nenergy.2016.24

Sovacool, B. K., Hook, A., Martiskainen, M., \& Baker, L. (2019). The whole systems energy injustice of four European low-carbon transitions. Global Environmental Change, 58, 101958

Taebi, B. (2017). Bridging the gap between social acceptance and ethical acceptability. Risk Analysis, 37(10), 1817-1827

Taebi, B., Correljé, A., Cuppen, E., Dignum, M., \& Pesch, U. (2014). Responsible innovation as an endorsement of public values: The need for interdisciplinary research. Journal of Responsible Innovation, $1(1), 118-124$

van de Grift, E., Cuppen, E., \& Spruit, S. (2020). Co-creation, control or compliance? How Dutch community engagement professionals view their work. Energy Research \& Social Science, 60, 101323

van den Beukel, J., \& Beckman, K. (2019). The great Dutch gas transition. Oxford Institute for Energy Studies, Oxford Energy Insight: 54, July 2020.

van den Beukel, J., \& van Geuns, L. (2020). Groningen gas: the loss of a social license to operate. The Hague Centre for Strategic Studies, HCSS geo-economics, januari 2020.

van der Linde, I. (2008). De slag om de Waddenzee: Een terugblik op vijf jaar politieke strijd. IMSA.

Van der Voort, N., \& Vanclay, F. (2015). Social impacts of earthquakes caused by gas extraction in the Province of Groningen, The Netherlands. Environmental Impact Assessment Review, 50, $1-15$

van Dijck, J., Poell, T., \& de Waal, M. (2016). De platformsamenleving: Strijd om publieke waarden in een online wereld. University Press.

Weijnen, M., Correljé, A. \& de Vries, L. (2015). Infrastructuren als wegbereiders van duurzaamheid, Working Paper nummer 12, Den Haag: Wetenschappelijke Raad voor het Regeringsbeleid (WRR).

Open Access This chapter is licensed under the terms of the Creative Commons Attribution 4.0 International License (http://creativecommons.org/licenses/by/4.0/), which permits use, sharing, adaptation, distribution and reproduction in any medium or format, as long as you give appropriate credit to the original author(s) and the source, provide a link to the Creative Commons license and indicate if changes were made.

The images or other third party material in this chapter are included in the chapter's Creative Commons license, unless indicated otherwise in a credit line to the material. If material is not included in the chapter's Creative Commons license and your intended use is not permitted by statutory regulation or exceeds the permitted use, you will need to obtain permission directly from the copyright holder.

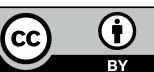

